Article

\title{
What Is the Level of People's Acceptance for Electric Taxis and Buses? Exploring Citizens' Perceptions of Transportation Electrification to Pay Additional Fees
}

\author{
Jean-Michel Clairand (I) and Mario González-Rodríguez *(i) \\ Facultad de Ingeniería y Ciencias Aplicadas, Universidad de las Américas-Ecuador, Quito 170122, Ecuador; \\ jean.clairand@udla.edu.ec \\ * Correspondence: mario.gonzalez.rodriguez@udla.edu.ec; Tel.: +593-9-58757173
}

Citation: Clairand, J.-M.

González-Rodríguez, M. What Is the Level of People's Acceptance for Electric Taxis and Buses?

Exploring Citizens' Perceptions of Transportation Electrification to Pay Additional Fees. World Electr. Veh. J 2022, 13, 3. https://doi.org/10.3390/ wevj13010003

Academic Editors: Joeri Van Mierlo and Grzegorz Sierpiński

Received: 8 November 2021 Accepted: 17 December 2021 Published: 24 December 2021

Publisher's Note: MDPI stays neutral with regard to jurisdictional claims in published maps and institutional affiliations.

Copyright: (C) 2021 by the authors Licensee MDPI, Basel, Switzerland. This article is an open access article distributed under the terms and conditions of the Creative Commons Attribution (CC BY) license (https:// creativecommons.org/licenses/by/ $4.0 /)$.

\begin{abstract}
Electric vehicles (EVs) are gradually addressing the environmental problem in cities created by internal combustion vehicles. However, to be widely used, a major challenge will still have to be tackled. Some significant challenges are the resistance to new technologies and EVs' purchase cost, which is significantly higher than that of internal combustion vehicles. These challenges are similar to the adoption of EVs for public transportation, such as buses and taxis. Thus, this paper proposes valuable insights into attitudes and preferences for taxi and bus users for the willingness to travel in EVs, by performing a convenience sampling, focusing especially on young users. Moreover, this study highlights the possibility of the users paying additional fees to travel in electric taxis (ETs) or electric buses (EBs). Pearson's chi-squared analysis was also performed to validate the hypotheses.
\end{abstract}

Keywords: community detection; data analytics; electric vehicle; social behavior; transportation systems; willingness to pay

\section{Introduction}

Human actions, including fossil fuel emissions, have contributed to the massive release into the atmosphere of carbon dioxide and other greenhouse gasses, which are interrupting the global carbon cycle and are contributing to global warming [1-4]. The transportation sector is responsible for a large share of greenhouse gas (GHG) emissions worldwide. Hence, it is essential to find new alternatives to reduce these emissions and to reduce the dependency on fossil fuels. Electric Vehicles (EVs) seem a promising solution to mitigate those problems $[5,6]$.

Although EVs have various benefits, they also have various challenges. For example, a massive penetration of EVs leads to power system issues [7,8]. Many researchers have therefore proposed various "smart charging" techniques to mitigate those issues. Smart charging of electric vehicles is an important field of research that allows EV users and grid operators to correctly manage EV charging profiles for technical and economic benefits and take into account the unique demand-side management needs of EVs [9-16].

The share of EVs in the total vehicle market is still minimal. This is due to there still being several barriers to purchasing EVs. In general, the economic barriers include a high initial cost of EVs and batteries. Social barriers include users' uncertainties concerning the EV technology.

Several initiatives for the penetration of EVs in the automotive market have been implemented in various countries, such as Australia [17], China [18], the United States [19] and European countries [20], among others.

In Ecuador these last years, there were a few initiatives to purchase EVs for public transportation. In 2017, in the southern city of Ecuador, Loja, a first ET pilot project was performed [21]. It consisted of offering fifty taxi places for the purchase of EVs. Some economic incentives from the government and the municipality were proposed to purchase the EV brands e4 from the Chinese company BYD and Soul EV from the Korean company 
Kia. In 2020, similarly in the western city Guayaquil, 50 ETs were purchased for a taxi fleet [22]. Some small pilot projects were also developed in Guayaquil and in Quito with the construction of fast EB charging stations and the purchase of some EBs [23].

The COVID-19 pandemic affected many aspects of society worldwide, especially in 2020. In particular, the transportation sector has to propose some changes to mitigate health issues due to contacts between people in mass public transportation. Thus, this survey has also considered a few elements of these changes in transportation.

Based on this information, and with the literature review presented in the next section, the question arises: What is the level of people's acceptance for electric taxis and buses? It is crucial to answer this question to properly plan the deployment of electric taxis and buses and define the correct tariffs for transportation.

The aim of this work is to analyze the attitudes and perceptions of bus and taxi users' for the electrification of those vehicles, especially of young users. Besides, due to the COVID-19 pandemic, some questions evaluated the necessary changes in transportation for health security reasons.

The rest of this paper is organized as follows: Section 2 reviews the related works. Section 3 presents the main methodology. Section 4 discusses the main results and findings. Finally, Section 5 is devoted to the conclusions.

\section{Related Works}

Various works have studied consumer perceptions for the adoption of EVs based on surveys. These studies include technical, social, economic, and environmental aspects. In [24], an analysis of consumer attitudes and perceptions was performed to highlight the barriers to adopting EVs. The biggest concern found was the EV range limitation and the high cost. The authors of [25] studied the interest of plus-in EVs to be purchased in 21 US cities, resulting in low interest. A similar survey was carried out by [26] in large US cities, with similar conclusions. The authors of [27] analyzed the consumer attitudes towards purchasing EVs in Spain. In [28], a survey was performed in Latvian municipalities. The authors of [29] investigated consumers' desire to buy electric vehicles in Shenzhen, China, and found a significant level of interest. In [30], consumer perceptions and personalities related to purchasing EVs in China were studied. The authors of [31] analyzed the perceptual and motivational reasons for the low adoption of EVs in Denmark. In [32], an evolution of the consumer preferences to purchase EVs and Plug-In Hybrid Vehicles (PHEVs) between 2011 and 2017 was performed. The authors of [33] focused their perception research on various brands of EVs. In [34], a structural equation modeling analysis using data gathered through an online survey was performed to assess the EV purchase intentions in Spain. This work was complemented by [35]. In [36], the potential buyers of Hybrid Electric Vehicles (HEVs) and PEVs were identified based on a survey in the United States.

Other studies focused on general perceptions of EV charging. For example, in [37], the recharging of EVs was studied in UK drivers. The authors of [38] assessed the current levels of visibility for public plug-in EV charging infrastructure within Canada. This study concludes that only $18 \%$ of respondents were aware of at least one public charger. In [39], the widespread ignorance or misunderstanding considering the technology of plug-in EVs compared to Hybrid Electric Vehicles (HEV) was analyzed. The authors of [40] asked children about EVs and conventional cars in Denmark and the Netherlands. In [41], the barriers to the adoption of PEVs in India and Sri Lanka were studied.

Segmentation analyses have also been performed for the EV market. In [42], a twostage cluster analysis methodology has been followed to identify market segments in a dataset of UK drivers, demonstrating that a significant degree of consumer stratification is present in the emerging market for EVs. The authors of [43] propose an Italian automobile user segmentation for full EVs based on the perceived attractiveness of the benefits of a full-electric city car offering and investigate whether various demographic factors designate the identified categories. In [44], market segmentation is conducted, with an emphasis on discovering commonalities in the features of electric car models in the Polish market and suggested groups. In [45], several European automobile taxation schemes are reviewed, 
and a methodology for computing CO2-based taxation step curves is proposed, allowing for a coherent comparison and overview.

Some other surveys analyzed new services and technologies for EVs, such as vehicle-togrid (V2G). For example, in [46], the near-term market for V2G was evaluated by analyzing the consumer's willingness to pay for V2G services. The authors of [47] studied the expectations of battery swapping stations. In [48], the impact of new mobility services such as car-sharing on EV sales was studied. The authors of [49] evaluated expert perceptions of Grid-to-Vehicle (G2V), Vehicle-to-Home (V2H), and V2G in the United States. In [50], a study was performed to understand whether current car users of new vehicle technologies will purchase EVs in California, USA.

Other works have analyzed the impacts of various incentives for the market of EVs. For example, in [51], various incentives, such as registration tax exemptions, free parking spaces and road tolls, among others, were analyzed in various cities in the world. The authors of [52] explored the effects of perceived risk, perceived usefulness, and financial incentive policy in ten pilot cities in China. In [53], the moderating effects of environmental traits and government support on EV purchase intention in Korea were examined. The authors of [54] proposed a structural equation model and a neural network approach to analyze various EV incentives for the customer's intention to purchase EVs in Zhejiang Province, China. All these works and others presented robust surveys and valuable analysis, resulting in crucial conclusions concerning the economic, technical, social, and legislative barriers and challenges for the massive adoption of EVs. However, all these works focused only on light and private EVs. To the knowledge of the authors, no work performed a perception survey related to EVs for public transportation, such as buses and taxis, which is the objective of this work.

\section{Methodology: Survey and Data Analysis}

A convenience sampling [55] was performed through an online questionnaire and was used to gather data from a sample population (see Appendix A). The target population includes Quito and Ecuador's citizens to capture perceptions, attitudes, and opinions related to replacing combustion buses and taxis with electric ones. The survey was intended for people using public transportation at least once a week. This will lead to possible cost changes, so this impact is evaluated.

As a result of the survey, 217 responses were obtained and used for analysis. The objective was to identify the attitudes and perceptions of bus and taxi users for the possible electrification of public transportation. A secondary objective of this work was to associate those socioeconomic characteristics with individual expectations and attitudes towards EVs, which included gender, age, dwelling place, and traveling behavior. We assume that these variables affect the beliefs and perceptions of individuals.

The collected data were processed into a dataset. Sociodemographic variables were collected together with user perception variables. An Exploratory Data Analysis (EDA) was carried out. Namely, the EDA was carried out on factor variables. Mosaic plots were the preferred tool to visualize and describe the correlations among the factor variables. Stacked percentage bar plots were also used according the nature of the responses analyzed [56]. The relation between the aforementioned demographics and user perception factor variables was quantified and the results are discussed as follows.

The survey was conducted on the first quarter of 2020, at the beginning of the pandemic year. A convenience sampling was performed through an electronic (Google) form.

\section{Results and Discussion}

\subsection{Sample Description}

The survey has a higher representation of males (59\%) compared to females (41\%). The respondents of this work are significantly young. In Ecuador, the 18-24 year old group represents almost $6 \%$ of the entire population, and the average age is 29 years old [57]. Moreover, this group of people is the most important sample that takes public transportation. Most people from the 54+ group do not travel much around the city and 
have their own vehicles. Most of the respondents live in the North of Quito, which is one of the richer zones in Quito. Furthermore, there was a pilot project of EBs. Quito's major willingness is to electrify electric buses and taxis due to the better electric distribution networks in the North of Quito. Thus, we have mainly focused on respondents from this area, and we considered some data of people that travel to the North of Quito. In Ecuador, the average salary is $\$ 324.9$ per month [58].

Table 1 summarizes this demographic information.

Table 1. Demographic summary of the sample.

\begin{tabular}{|c|c|c|}
\hline & Number & Share $(\%)$ \\
\hline \multicolumn{3}{|l|}{ Gender } \\
\hline Male & 128 & 59 \\
\hline Female & 89 & 41 \\
\hline \multicolumn{3}{|l|}{ Age } \\
\hline $18-24$ & 116 & 53 \\
\hline 25-34 & 48 & 22 \\
\hline $35-44$ & 28 & 13 \\
\hline $45-54$ & 15 & 7 \\
\hline$>54$ & 10 & 5 \\
\hline \multicolumn{3}{|c|}{ Starting point of the journey } \\
\hline Los Chillos & 34 & 16 \\
\hline Tumbaco & 22 & 10 \\
\hline Mitad del Mundo & 6 & 3 \\
\hline Carapungo-Calderón & 9 & 4 \\
\hline South of Quito & 29 & 13 \\
\hline North of Quito & 103 & 47 \\
\hline Old City & 14 & 6 \\
\hline \multicolumn{3}{|l|}{ Trip Duration } \\
\hline$<20 \mathrm{~min}$ & 41 & 37 \\
\hline $21-30 \mathrm{~min}$ & 36 & 32 \\
\hline $31-40 \mathrm{~min}$ & 19 & 17 \\
\hline $41-50 \mathrm{~min}$ & 10 & 9 \\
\hline$>50 \mathrm{~min}$ & 5 & 5 \\
\hline \multicolumn{3}{|l|}{ Trip Distance } \\
\hline$<8 \mathrm{~km}$ & 36 & 32 \\
\hline $8-15$ km & 49 & 44 \\
\hline $16-23 \mathrm{~km}$ & 10 & 9 \\
\hline $24-31 \mathrm{~km}$ & 8 & 7 \\
\hline $32-39 \mathrm{~km}$ & 7 & 6 \\
\hline$>39 \mathrm{~km}$ & 1 & 1 \\
\hline
\end{tabular}

\subsection{Description of Bus Users}

From the respondents, only $63 \%$ travel by bus at least one time per week. This means that the other respondents have their own vehicle or travel by taxi, foot, or bike.

Most of the bus users wait from 5 to $10 \mathrm{~min}(44 \%)$, which is a relatively quick time. However, $11 \%$ of the users wait more than $20 \mathrm{~min}$.

In terms of travel bus costs, most people spend $\$ 1$ or less per day ( $38 \%$ for $\$ 0.50$ and $40 \%$ for $\$ 1$ ). Note that the cost of a single trip in a bus in Quito is $\$ 0.25$, so a $\$ 0.50$ fare means a two-way trip, and a $\$ 1$ trip means a two-way trip considering the need to travel in two different buses to reach the destination. This information is summarized in Table 2. 
Table 2. Demographic summary of the bus users.

\begin{tabular}{lcc}
\hline & Number & Share (\%) \\
\hline Frequency of use & & \\
Don't travel by bus & 81 & 37 \\
1 per week & 18 & 8 \\
2 per week & 12 & 6 \\
3 per week & 9 & 4 \\
4 per week & 10 & 5 \\
5 or more per week & 87 & 40 \\
Waiting Time & & \\
$<5$ min & 10 & 7 \\
$5-10$ min & 60 & 44 \\
$10-20$ min & 51 & 37 \\
$>20$ min & 15 & 11 \\
\hline Cost of travel per day & & \\
$\$ 0.50$ & 51 & 38 \\
$\$ 1$ & 55 & 40 \\
$\$ 1.25$ & 12 & 9 \\
$\$ 1.50$ & 8 & 6 \\
$>\$ 1.50$ & 10 & 7 \\
\hline
\end{tabular}

\subsection{Description of Taxi Users}

From the respondents, only $51 \%$ travel by taxi at least one time per week. This means that the other respondents have their own vehicle or travel by bus, feet, or bike.

Most of the bus users wait from 5 to $10 \mathrm{~min}(49 \%)$, which is a relatively quick time. However, $13 \%$ of the users wait more than $10 \mathrm{~min}$.

In terms of travel bus costs, most of the people spend $\$ 4$ or less per day, with $15 \%$ of users who spend less than $\$ 2$ per trip. The start of the taxi trip in Quito is $\$ 0.50$ with a driven cost of $0.40 \$ / \mathrm{km}$, and considering a minimum cost trip of a taxi of $\$ 1.45$ during the day and $\$ 1.75$ in the night. This information is summarized in Table 3.

Table 3. Demographic summary of the taxi users.

\begin{tabular}{lcc}
\hline & Number & Share (\%) \\
\hline Don't travel by taxi & 106 & 49 \\
1 per week & 52 & 24 \\
2 per week & 25 & 12 \\
3 per week & 12 & 6 \\
4 per week & 5 & 2 \\
5 or more per week & 17 & 8 \\
\hline Waiting Time & & \\
$<5$ min & 43 & 39 \\
$5-10$ min & 54 & 49 \\
$10-20$ min & 13 & 12 \\
$>20$ min & 1 & 1 \\
\hline Cost of single travel & & \\
$<\$ 2$ & 17 & 15 \\
$\$ 2-3$ & 30 & 27 \\
$\$ 3-4$ & 31 & 28 \\
$\$ 4-6$ & 27 & 24 \\
$\$ 6-8$ & 4 & 4 \\
$>\$ 8$ & 2 & 2 \\
\hline
\end{tabular}


Figure 1 depicts the bar chart of the customer preferences related to the kind of service for taxis. Note that Uber is the taxi service that is preferred by most of the respondents with more than a half of the respondents that selected it as their first choice. This is because in Quito this taxi app is now widely used and many users like this service due to the security that Uber offers. Moreover, it can be seen that the other taxi app services are not much used.

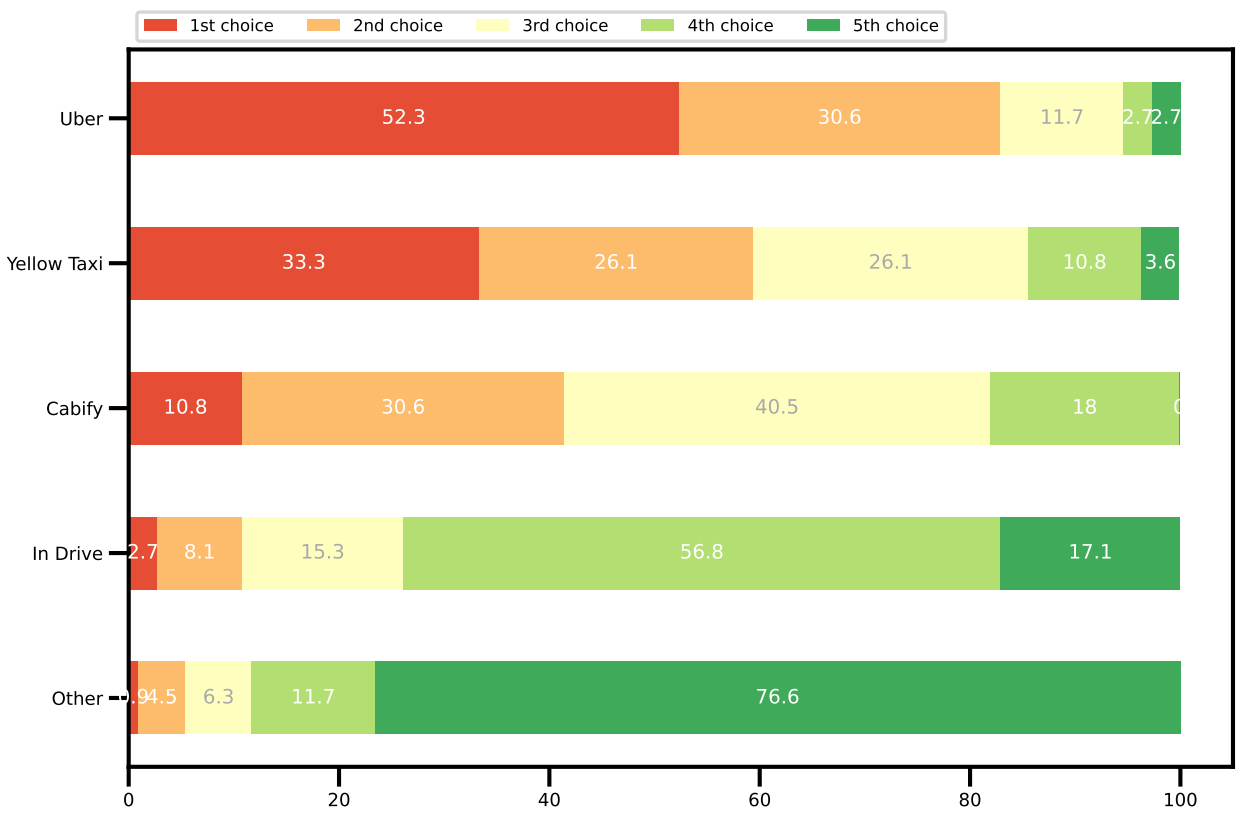

Figure 1. Bar chart of the preferences of service types of taxis.

\subsection{Attitudes and Perceptions Towards Electric Public Transportation}

\subsubsection{Type of Energy Use}

Overall, 69\% of the total respondents will prefer EBs and ETs, while 22\% do not care about the type of energy used for transportation, and $9 \%$ prefer fossil fuels.

In Figure 2, a mosaic plot considering the age and the preferred type of energy use for transportation is illustrated. Observe that people that are between 25 and 34 years old are more sensitive to preferring electric public transportation. On the other hand, there is a significant proportion of people between 18 to 24 years old that do not care about electrified public transportation or prefer it to be powered by fossil fuels. There were no statistically significant differences in concerns based on genre. 


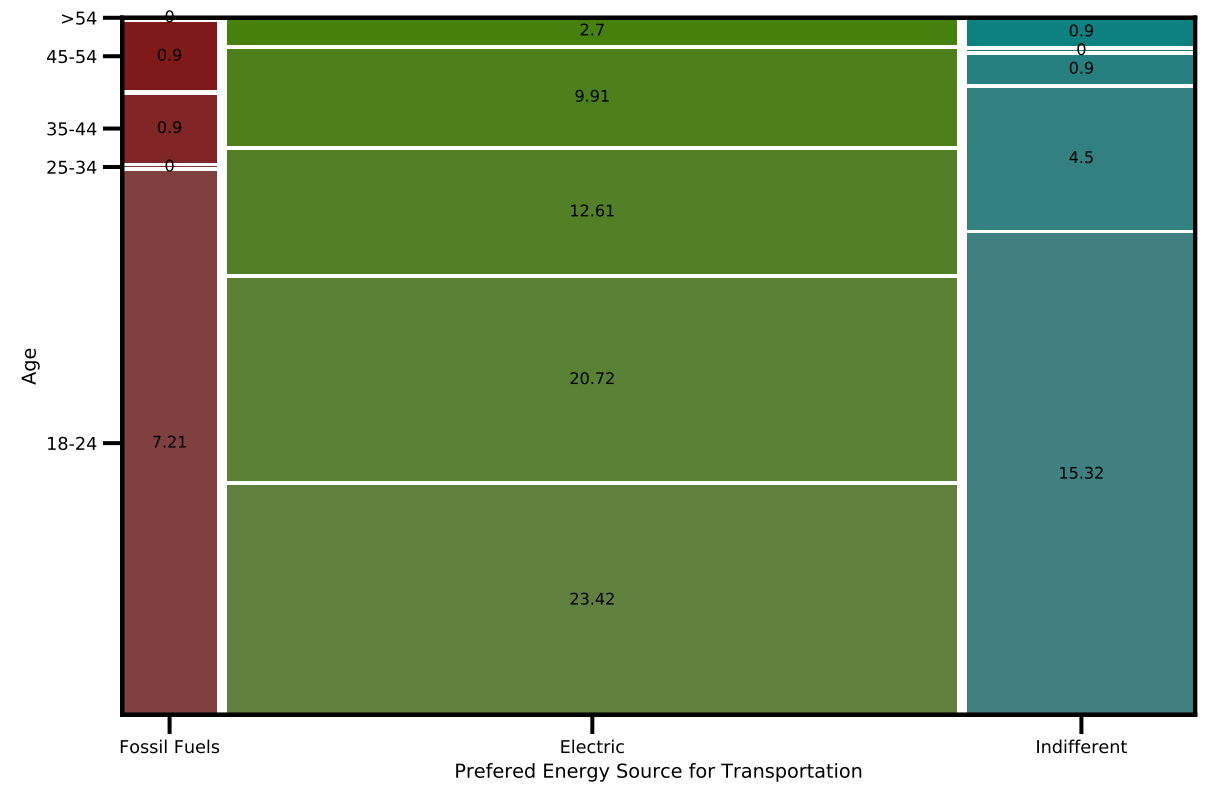

Figure 2. Mosaic plot of the preferred energy source for transportation based on age.

\subsubsection{Willingness to Pay an Additional Value}

The perceptions indicate that $64 \%$ of the respondents are willing to pay an additional fee to travel in EVs without considering any additional incentive. In Figure 3, a mosaic plot of this perception is represented, considering the gender. It is observed that women are overall more willing to pay an additional fee for traveling in EVs than men.

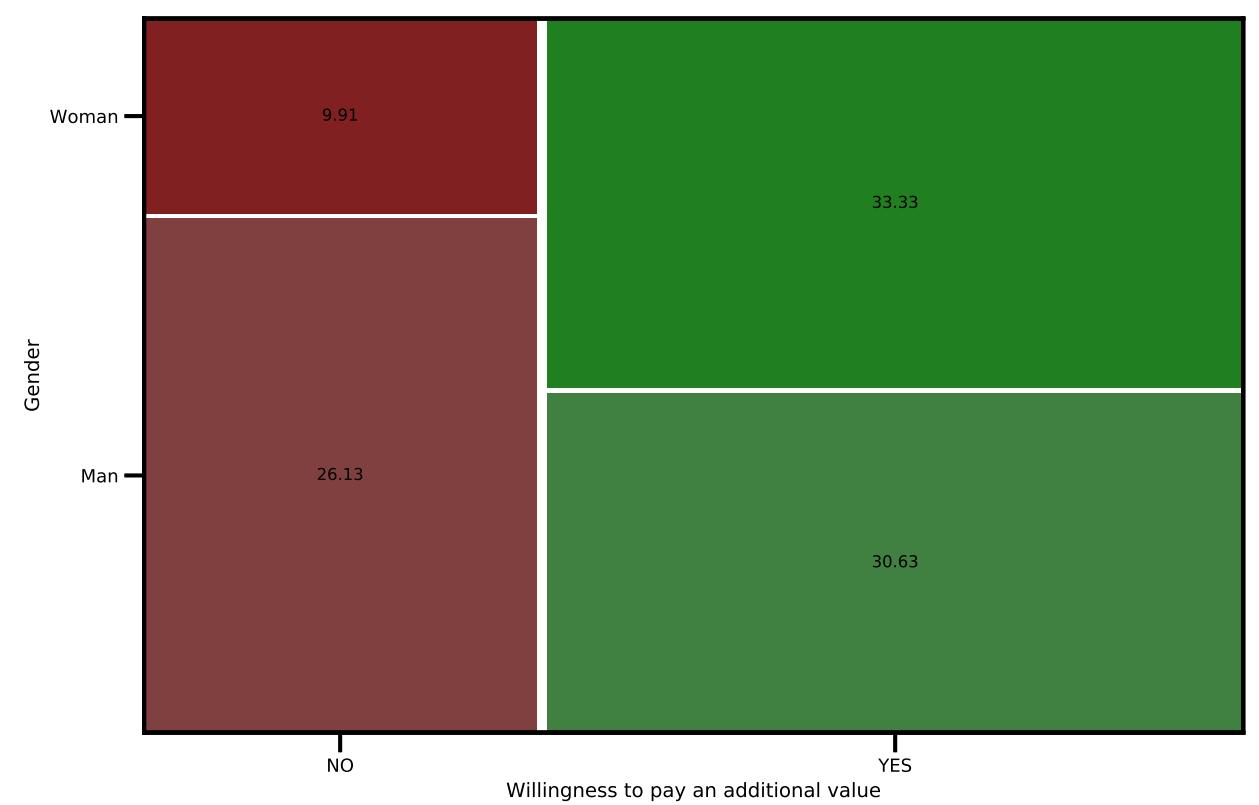

Figure 3. Mosaic plot of the willingness to pay an additional value based on gender.

A Pearson's chi-squared test was performed to determine whether there is a statistically significant difference between the expected frequencies and the observed frequencies for categorical variables in a contingency table, such as Gender/Willingness to pay extra [59]. Table 4 depicts the observed and expected frequencies (in parenthesis). 
Table 4. Observed and expected frequencies.

\begin{tabular}{ccc}
\hline & \multicolumn{2}{c}{ Willingness to Pay More } \\
Gender & No & Yes \\
\hline Male & $29(22.7)$ & $34(40.3)$ \\
Gemale & $11(17.3)$ & $37(30.7)$ \\
\hline
\end{tabular}

The null hypothesis is that there is no observed difference between the observed frequencies according to gender. The Pearson's chi-square test resulted in a $p$-value of 0.0120 , indicating evidence against the null hypothesis; thus, we can conclude that there is a difference in the willingness to pay more to use EVs according to the gender of the respondent.

Similarly, in Tables 5 and 6, the results of a Pearson's chi-squared test considering Average Time/Willingness to Pay more and Average Distance/Willingness to Pay more are summarized.

Table 5. Observed and expected willingness to pay more based on trip duration.

\begin{tabular}{ccc}
\hline & \multicolumn{2}{c}{ Willingness to Pay More } \\
Trip Average Time (min) & No & Yes \\
\hline $21-30$ & $13(12.97)$ & $23(23.03)$ \\
$31-40$ & $8(6.95)$ & $11(23.03)$ \\
$41-50$ & $2(3.6)$ & $8(23.03)$ \\
$>51$ & $1(1.8)$ & $4(23.03)$ \\
$<20$ & $16(14.77)$ & $25(23.03)$ \\
\hline
\end{tabular}

The Pearson's chi-square test resulted in a $p$-value of 0.71 , indicating no evidence against the null hypothesis; thus, we can conclude that there is no difference in the willingness to pay more to use EVs according to the average time of the trips. A similar result is found for the average distance of the trips. The Pearson's chi-square test resulted in a $p$-value of 0.34 , indicating no evidence against the null hypothesis; thus, we can conclude that there is no difference in the willingness to pay more to use EVs according to the average distance (kilometers) of the trips.

Table 6. Observed and expected willingness to pay more based on trip distance.

\begin{tabular}{ccc}
\hline & \multicolumn{2}{c}{ Willingness to Pay More } \\
Trip Average Distance $\mathbf{( k m )}$ & No & Yes \\
\hline $16-23$ & $4(3.6)$ & $6(6.4)$ \\
$24-31$ & $1(2.88)$ & $7(5.12)$ \\
$32-39$ & $1(2.52)$ & $6(4.48)$ \\
$88-15$ & $20(17.66)$ & $29(31.34)$ \\
$>39$ & $1(0.36)$ & $0(0.64)$ \\
$<8$ & $13(12.97)$ & $23(23.03)$ \\
\hline
\end{tabular}

In Figure 4, a mosaic plot of this perception is represented considering age. It is observed that people between 18 and 24 years old are less willing to pay an additional fee to travel in EVs. This could be because this group of people does not have their own incomes in general. On the other side, people from 25 to 34 are more willing to pay an additional fee. 


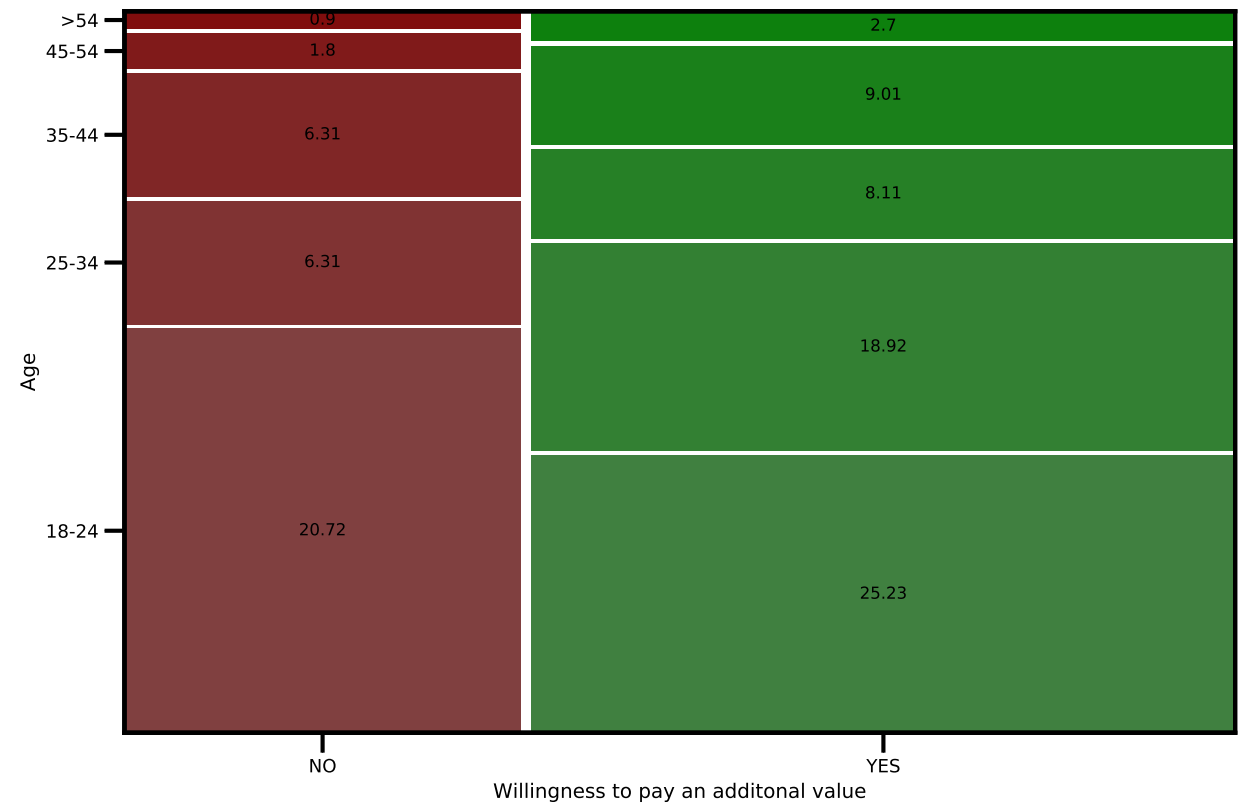

Figure 4. Mosaic plot of the willingness to pay an additional value based on age.

Next, the purpose was to assess the upper limit regarding an additional fee that users will be willing to pay for taking ETs or EBS. Exceeding this additional fee, the users will consider not taking a bus or taxi.

For ETs, the maximum additional value was first evaluated without an incentive. Then it was evaluated considering a privileged route, which reduces the travel time that is a proper incentive for taxi users. In Table 7, the results for ETs are summarized. Note that half of the respondents are willing to pay $\$ 0.75$ or more without any additional incentive for taking an ET. The minimum fare for a taxi ride in Quito is 1.50 USD. This can go up to $\$ 25$ for a taxi ride to the international airport. The mean ride costs $4-5$ dollars, around a $15 \%$ to $20 \%$ additional incentive for taking an ET. Moreover, with the privileged route incentive, it can be noted that some users are willing to pay a little more than without this incentive; however, it seems that this incentive is not particularly motivating.

Table 7. Maximum additional fee for ETs.

\begin{tabular}{lcc}
\hline & Number & Share (\%) \\
\hline No additional incentive & & \\
$\$ 0.25$ & 36 & 32 \\
$\$ 0.50$ & 20 & 18 \\
$\$ 0.75$ & 17 & 15 \\
$\$ 1$ & 20 & 18 \\
$\$ 1.50$ & 18 & 16 \\
\hline Privileged Route & & \\
$\$ 0.50$ & 39 & 35 \\
$\$ 0.75$ & 25 & 23 \\
$\$ 1$ & 25 & 23 \\
$\$ 1.50$ & 22 & 20 \\
\hline
\end{tabular}

In Figures 5 and 6, the mosaic plots of genre and age are depicted. Observe that women are in general willing to pay more to travel in an ET, while people between 25 and 34 are in the group that is willing to pay more, while the group aged between 35 and 44 are the group that is less willing to pay an additional fee for traveling in an ET. 


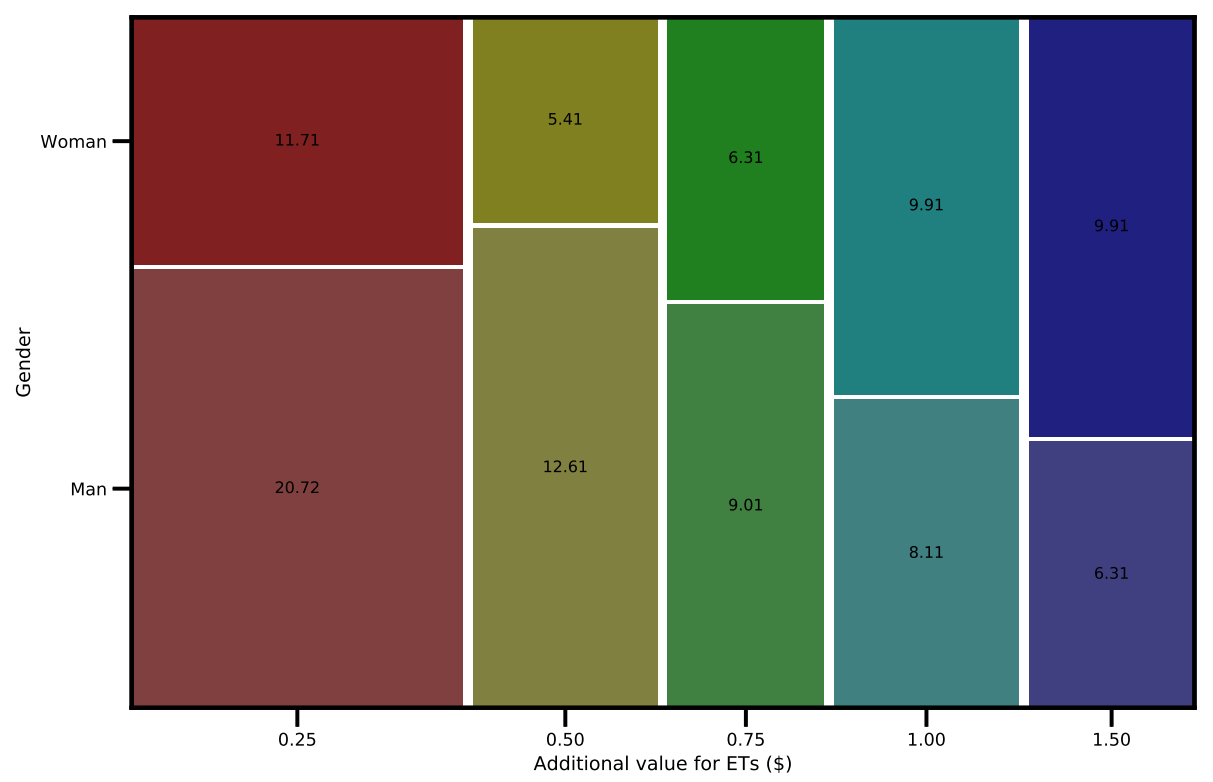

Figure 5. Mosaic plot of the willingness to pay an additional value for ETs based on gender.

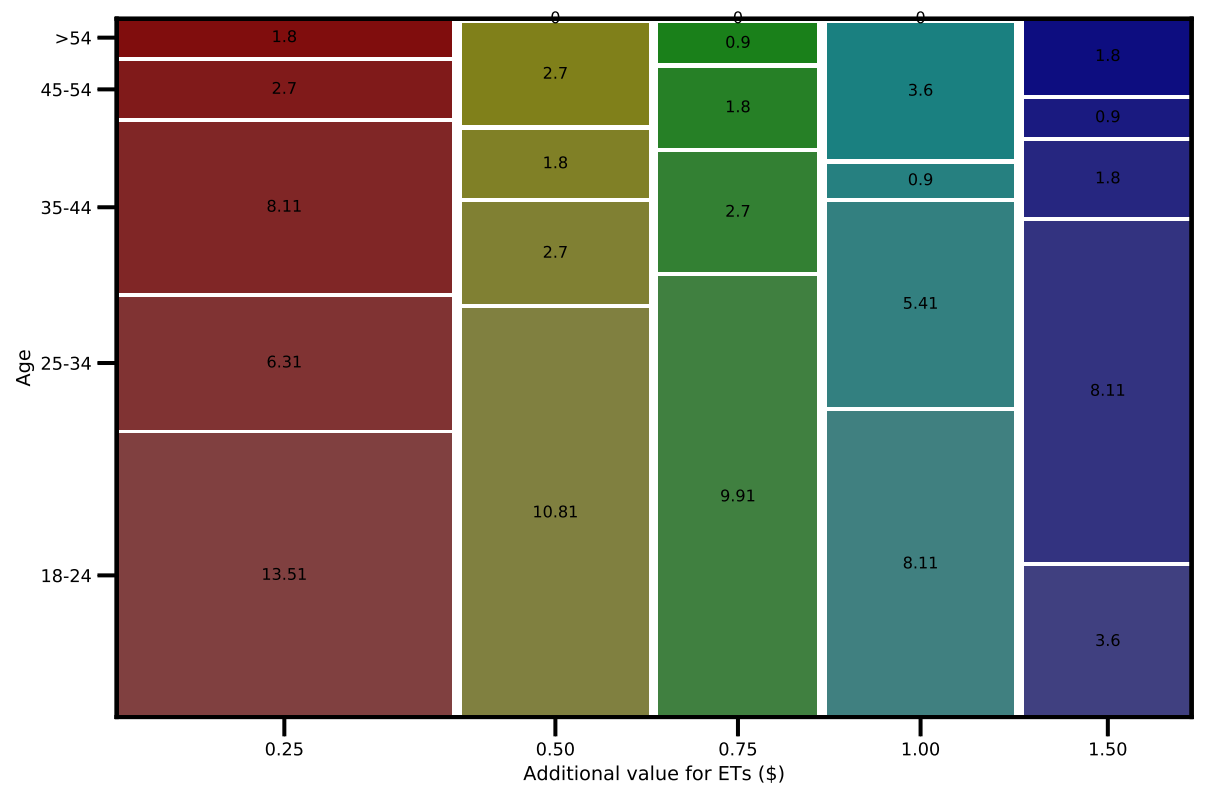

Figure 6. Mosaic plot of the willingness to pay an additional value for ETs based on age.

For EBs, the maximum additional value was only evaluated without an incentive since buses already have pre-defined routes in the city and, in some cases, they are already privileged. In Table 8, the results for ETs are summarized. Note that more than half (55\%) of the respondents are willing to pay $\$ 0.25$ or more for traveling in an EB.

Table 8. Maximum additional fee for EBs.

\begin{tabular}{lcc}
\hline Additional Fee for Bus & Number & Share (\%) \\
\hline$\$ 0.10$ & 24 & 22 \\
$\$ 0.15$ & 14 & 13 \\
$\$ 0.20$ & 12 & 11 \\
$\$ 0.25$ & 22 & 20 \\
$\$ 0.30$ & 39 & 35 \\
\hline
\end{tabular}


In Figures 7 and 8, the mosaic plots of genre and age are depicted for EBs. The results are similar to the case for ETs: women are in general willing to pay more to travel in an EB, while people aged between 25 and 34 are in the group that is willing to pay more, while the group of 35 to 44 year-olds are less willing to pay an additional fee for traveling in an EB.

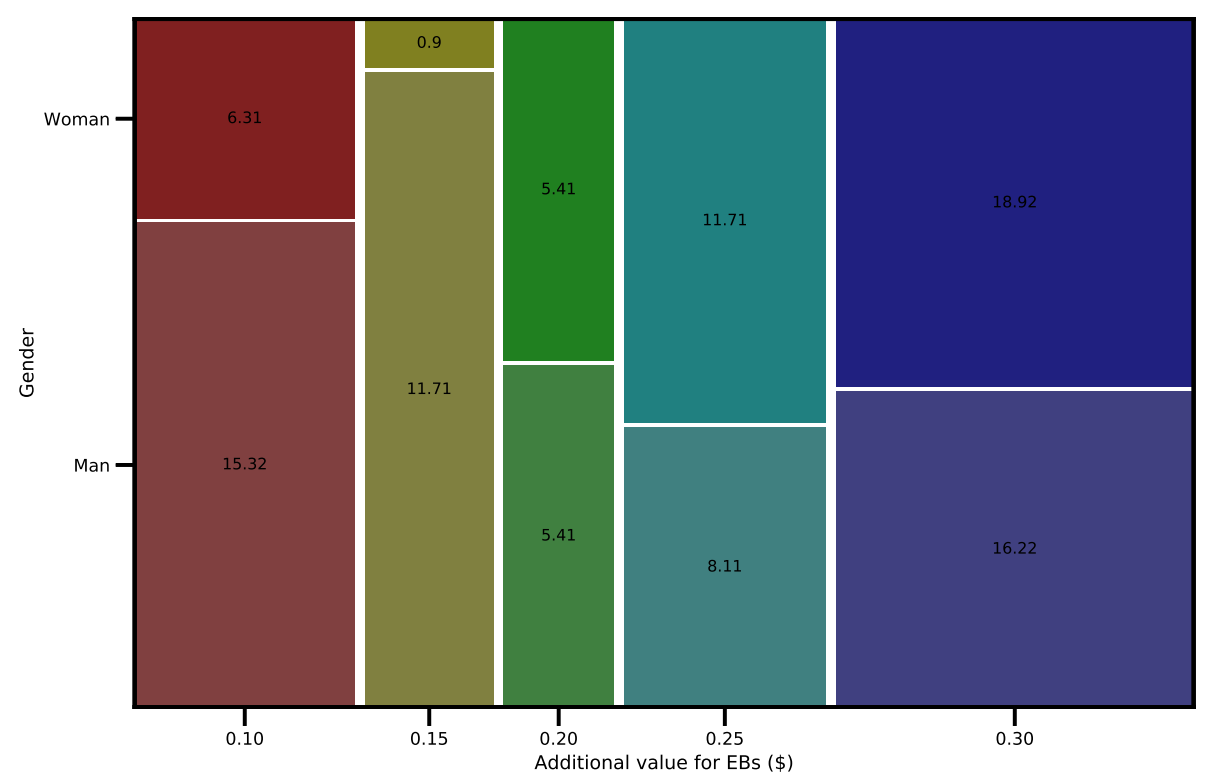

Figure 7. Mosaic plot of the willingness to pay an additional value for EBs based on gender.

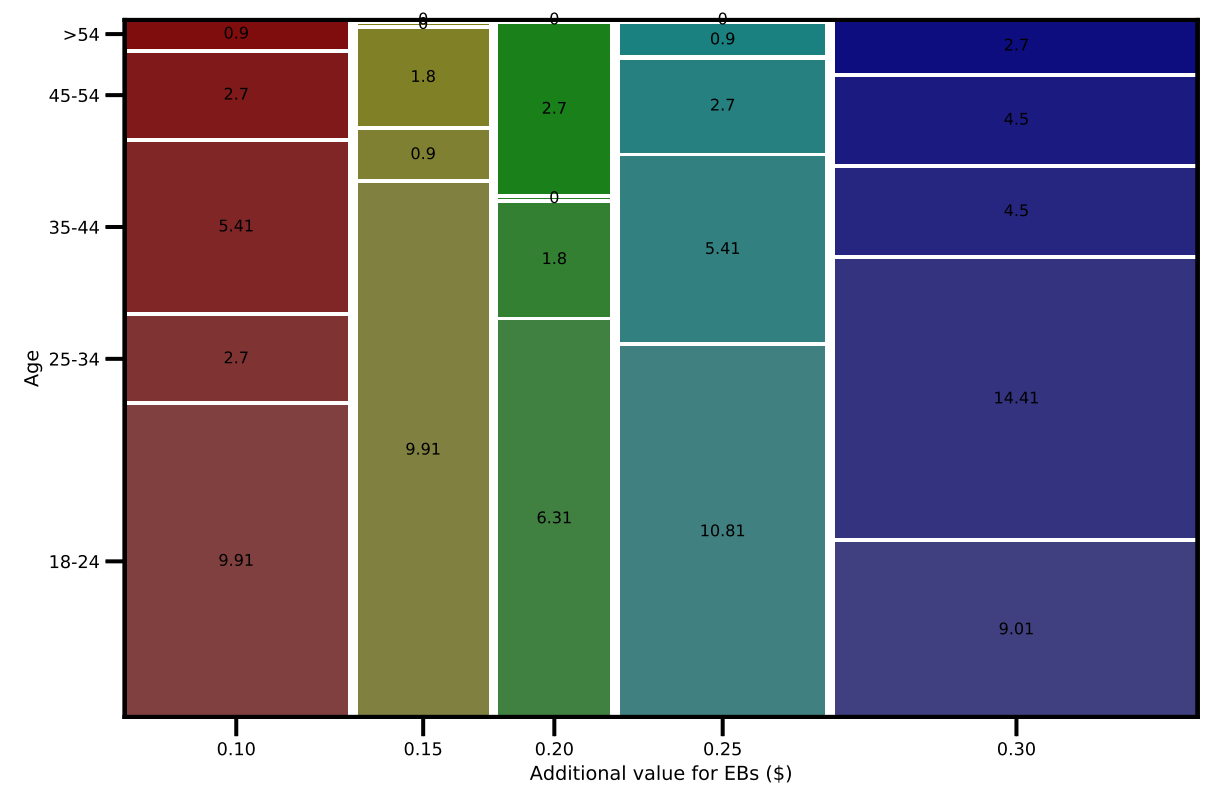

Figure 8. Mosaic plot of the willingness to pay an additional value for EBs based on age.

\subsubsection{Concerns for EVs}

Some of the most critical concerns for users were suggested to the respondents: vehicle speed, vehicle security, range autonomy, and comfort. From the respondents, the primary concern is the range autonomy with $63 \%$, then the speed vehicle with $19 \%$, vehicle security with 15\%, and finally comfort with $9 \%$. As illustrated in Figure 9, it seems that range autonomy and the speed of the vehicle are significant concerns for men. In contrast, vehicle security and comfort are significant concerns for women. There were no statistically significant differences in concerns based on age. 


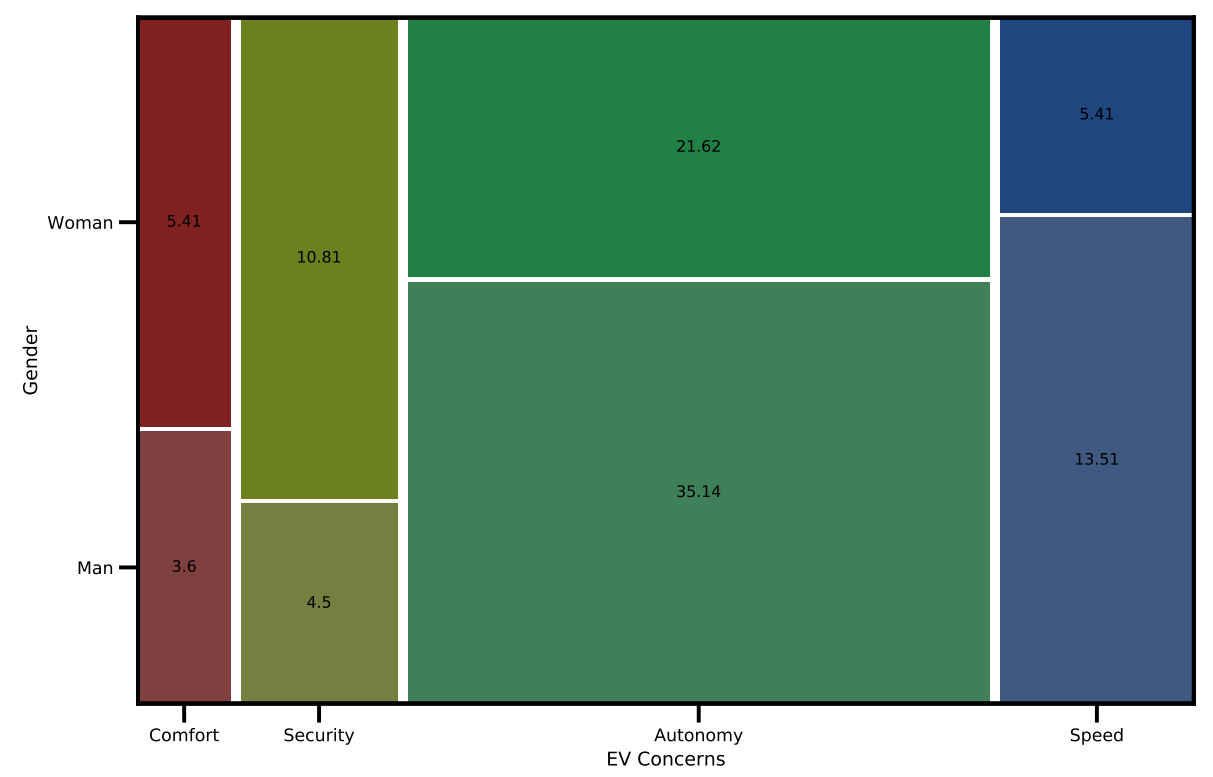

Figure 9. Mosaic plot of the EV concerns based on gender.

\subsection{Alternatives and Issues of Public Transportation Due to COVID-19}

Due to COVID-19, some other possibilities of transportation were evaluated by the respondents. The results show that $38 \%$ of the respondents would like to travel by bike, $37 \%$ by foot, $16 \%$ by motorcycle, and finally $8 \%$ by electric scooter, which is gaining more attention in Quito.

Considering the main issues for public transportation, $32 \%$ of the respondents believe that the cleaning should be improved, 33\% believe that there is a lack of security distance between passengers, 19\% believe that there is a lack of electronic payment. Finally, $16 \%$ of the respondents believe there is a lack of hydro-alcoholic gel.

\section{Conclusions}

This paper studied the attitudes and perceptions towards the electrification of public transportation, such as buses and taxis. A web survey was responded to by 217 people, considering gender, age, and starting point of the journey. Some characteristics of the trip were first evaluated, such as the trip duration and distance, frequency of use, waiting time, and cost of travel for buses and taxis.

It is interesting to note that the respondents are open to a variety of transportation options, to decrease the usage of gas-based transports. It was also found, in the hypothesis testing (Pearson's chi-squared), that the trip time and trip distance do not influence the willingness to pay extra for an Electric Taxi.

The perception of traveling in EVs was then evaluated considering a possible additional fee, which has to be considered since the cost of EVs is higher than that of internal combustion vehicles. Overall, the respondents feel confident to travel in EBs or ETs, despite some respondents' concerns such as the range autonomy and vehicle speed. It should be highlighted that the groups that were willing to pay more for traveling in EBs or ETs are women and people between 25 and 34 years old.

According to the performed hypothesis test (Pearson's chi-squared), women are more inclined to pay for electric trips than men; possibly they care about a more comfortable and environmentally friendly trip than men. Finally, a few perceptions were given, considering the issues of COVID-19 for public transportation. The results of this paper will be helpful for policymakers to analyze the proper planning of EVs for public transportation in a city like Quito.

A more involved analysis is guaranteed for future work, such as Exploratory Factor Analysis to group variables together and understand common factors of user perception 
variables. A principal component analysis accompanied by a cluster analysis were used, to group users with similar perceptions and understand their common characteristics.

Author Contributions: Conceptualization, J.-M.C.; Data curation, M.G.-R.; Formal analysis, J.-M.C., M.G.-R.; Investigation, J.-M.C., M.G.-R.; Methodology, M.G.-R.; Supervision, J.-M.C., M.G.-R.; Validation, J.-M.C., M.G.-R.; Writing—original draft, J.-M.C; Writing—review \& editing, M.G.-R. CRediT taxonomy for the term explanation. Authorship must be limited to those who have contributed substantially to the work reported. All authors have read and agreed to the published version of the manuscript.

Funding: This paper belongs to the projects SIS.JCG.19.03 and SIS.MGR.21.01 from Universidad de las Américas-Ecuador.

Institutional Review Board Statement: Not applicable.

Informed Consent Statement: Not applicable.

Data Availability Statement: Not applicable.

Acknowledgments: The authors would like to thank Paulo Guerra-Terán from Universidad de las Américas, Ecuador, for conceiving the survey, and Irvin Cedeño from BYD E-Motors Ecuador, and Guillermo Escrivá-Escrivá from Universitat Politècnica de València, for the fruitful discussion.

Conflicts of Interest: The authors declare no conflict of interest.

\section{Abbreviations}

The following abbreviations are used in this manuscript:

$\begin{array}{ll}\text { EB } & \text { Electric Bus } \\ \text { EV } & \text { Electric Vehicle } \\ \text { ET } & \text { Electric Taxi } \\ \text { G2V } & \text { Grid-to-Vehicle } \\ \text { HEV } & \text { Hybrid Electric Vehicle } \\ \text { PEV } & \text { Plug-in Electric Vehicle } \\ \text { PHEV } & \text { Plug-in and Hybrid Electric Vehicle } \\ \text { V2G } & \text { Vehicle-to-Grid } \\ \text { V2H } & \text { Vehicle-to-Home }\end{array}$

\section{Appendix A. Questions of the Survey}

1. What is your gender?

2. How old are you?

3. From which sector of Quito does your daily trip start?

4. How often do you travel by bus?

5. In the case of using the bus, how much is the usual average waiting time until the arrival of the bus?

6. In general, how much do you spend on the bus on average per day?

7. How often do you travel by taxi?

8. Considering the most common route, in general, how much do you spend in a taxi on the trip you make?

9. Sort by frequency of use, the type of service you use. (greater use above)

10. Considering the most common journey, how long does it usually take for the journey you take?

11. Considering the most common route, how many kilometers per trip does you travel on average?

12. Select the type of energy you would prefer in the means of transport (taxi or bus)

13. If you have to travel in a taxi or electric bus, would you be willing to pay an additional cost (at the regular rate of transportation that uses gasoline)?

14. What do you think is your biggest concern about electric vehicles? 
15. In the case of paying an additional value (for commitment to the environment). From what additional value, you would no longer take an electric taxi?

16. In the case of paying an additional value for using a privileged route for electric vehicles (reducing the time of arrival at the destination). From what additional value, you would no longer take an electric taxi?

17. In the case of paying an additional value at the current cost of $\$ 0.25$ (for commitment to the environment). From what increment, you would no longer take an electric bus?

18. Would you consider transporting yourself using any of the following COVID-19 alternatives?

19. What aspects do you think are missing in mass transport?

\section{References}

1. Clairand, J.M.; Serrano-Guerrero, X.; González-Zumba, A.; Escrivá-Escrivá, G. Techno-Economic Assessment of Renewable Energy-based Microgrids in the Amazon Remote Communities in Ecuador. Energy Technol. 2021, 2100746, in press. [CrossRef]

2. Serrano, X.; Narváez, M.; Urigüen, C.; Escrivá-Escrivá, G. Quantitative assessment of hybrid systems of heating domestic water based on solar energy in andean zones of Ecuador. In Proceedings of the 2016 51st International Universities Power Engineering Conference (UPEC), Coimbra, Portugal, 6-9 September 2016; pp. 1-6.

3. Benalcazar, P. Sizing and optimizing the operation of thermal energy storage units in combined heat and power plants: An integrated modeling approach. Energy Convers. Manag. 2021, 242, 114255. [CrossRef]

4. Vyas, S.; Kumar, R. Computational geometry-based methodology for identification of potential islanding initiators in high solar PV penetration distribution feeders. IET Renew. Power Gener. 2018, 12, 456-462. [CrossRef]

5. Nazaripouya, H.; Wang, B.; Black, D. Electric Vehicles and Climate Change: Additional Contribution and Improved Economic Justification. IEEE Electrif. Mag. 2019, 7, 33-39. [CrossRef]

6. Samuel, P.; Eddaaif, R.; González-Zumba, A.; Clairand, J.M. Assessment of the Impact of Electric Vehicle Batteries in the Non-Linear Control of DC Microgrids. Appl. Sci. 2021, 11, 4415. [CrossRef]

7. Soares, F.J.; Rua, D.; Gouveia, C.; Tavares, B.D.; Coelho, A.M.; Lopes, J.A. Electric Vehicles Charging: Management and Control S. IEEE Veh. Technol. Mag. 2018, 88, 54-78. [CrossRef]

8. Clairand, J.M.; Gonzalez-Rodriguez, M.; Kumar, R.; Vyas, S.; Escriva-Escriva, G. Coordinated Siting and Sizing of Electric Taxi Charging Stations Considering Traffic and Power Systems Conditions. In Proceedings of the 2021 IEEE Madrid PowerTech, PowerTech 2021, Madrid, Spain, 28 June-2 July 2021. [CrossRef]

9. Clement-Nyns, K.; Haesen, E.; Driesen, J. The impact of vehicle-to-grid on the distribution grid. Electr. Power Syst. Res. 2011, 81, 185-192. [CrossRef]

10. Veldman, E.; Verzijlbergh, R.A. Distribution grid impacts of smart electric vehicle charging from different perspectives. IEEE Trans. Smart Grid 2015, 6, 333-342. [CrossRef]

11. Sharma, I.; Bhattacharya, K.; Canizares, C.; Bhattacharya, K. Smart Charging of PEVs Penetrating Into Residential Distribution Systems. IEEE Trans. Smart Grid 2014, 5, 1196-1209. [CrossRef]

12. van der Kam, M.; van Sark, W. Smart charging of electric vehicles with photovoltaic power and vehicle-to-grid technology in a microgrid; a case study. Appl. Energy 2015, 152, 20-30. [CrossRef]

13. Clairand, J.M.; Rodriguez Garcia, J.; Alvarez Bel, C. Smart Charging for an Electric Vehicle Aggregator Considering User Tariff Preference. In Proceedings of the 2017 IEEE Power \& Energy Society Innovative Smart Grid Technologies Conference (ISGT), Washington, DC, USA, 23-26 April 2017; p. 5. [CrossRef]

14. Morais, H.; Sousa, T.; Castro, R.; Vale, Z. Multi-objective electric vehicles scheduling using elitist non-dominated sorting genetic algorithm. Appl. Sci. 2020, 10, 7978. [CrossRef]

15. Zhang, Q.; Hu, Y.; Tan, W.; Li, C.; Ding, Z. Dynamic time-of-use pricing strategy for electric vehicle charging considering user satisfaction degree. Appl. Sci. 2020, 10, 3247. [CrossRef]

16. Travaillé, P.; Benamar, A.; Clairand, J.M.; Escrivá-Escrivá, G. Operation of DC Microgrids Considering Different Strategies of Electric Vehicle Charging. In Proceedings of the 2020 IEEE ANDESCON, Quito, Ecuador, 13-16 October 2020; pp. 1-5. [CrossRef]

17. Broadbent, G.H.; Metternicht, G.; Drozdzewski, D. An analysis of consumer incentives in support of electric vehicle uptake: An Australian case study. World Electr. Veh. J. 2019, 10, 11. [CrossRef]

18. Li, W.; Long, R.; Chen, H.; Chen, F.; Zheng, X.; Yang, M. Effect of policy incentives on the uptake of electric vehicles in China. Sustainability 2019, 11, 3323. [CrossRef]

19. Jenn, A.; Springel, K.; Gopal, A.R. Effectiveness of electric vehicle incentives in the United States. Energy Policy 2018, 119, 349-356. [CrossRef]

20. Santos, G.; Davies, H. Incentives for quick penetration of electric vehicles in five European countries: Perceptions from experts and stakeholders. Transp. Res. Part A Policy Pract. 2020, 137, 326-342. [CrossRef]

21. El Telégrafo. Primera flota Eléctrica de Taxis Cumple 2 Años. Available online: https://www2.eltelegrafo.com.ec/noticias/ ecuador/1/taxiselectricos-loja-byd (accessed on 8 November 2021). 
22. El Universo. 50 Taxis eléctricos Circulan Desde hoy en las Calles de Guayaquil. Available online: https://www.eluniverso.com/ guayaquil/2020/10/22/nota/8022853/taxis-electricos-guayaquil-circulan-transito-movilidad (accessed on 8 November 2021).

23. El Comercio. Transportistas de Quito Planean Comprar 150 buses Eléctricos para Mejorar la Movilidad. Available online: https:/ / www.elcomercio.com/actualidad/transportistas-quito-compra-buses-electricos.html (accessed on 8 November 2021).

24. Egbue, O.; Long, S. Barriers to widespread adoption of electric vehicles: An analysis of consumer attitudes and perceptions. Energy Policy 2012, 48, 717-729. [CrossRef]

25. Krause, R.M.; Carley, S.R.; Lane, B.W.; Graham, J.D. Perception and reality: Public knowledge of plug-in electric vehicles in 21 U.S. cities. Energy Policy 2013, 63, 433-440. [CrossRef]

26. Carley, S.; Krause, R.M.; Lane, B.W.; Graham, J.D. Intent to purchase a plug-in electric vehicle: A survey of early impressions in large US cites. Transp. Res. Part D Transp. Environ. 2013, 18, 39-45. [CrossRef]

27. Junquera, B.; Moreno, B.; Álvarez, R. Analyzing consumer attitudes towards electric vehicle purchasing intentions in Spain: Technological limitations and vehicle confidence. Technol. Forecast. Soc. Chang. 2016, 109, 6-14. [CrossRef]

28. Barisa, A.; Rosa, M.; Kisele, A. Introducing Electric Mobility in Latvian Municipalities: Results of a Survey. Energy Procedia 2016, 95, 50-57. [CrossRef]

29. Wang, F.P.; Yu, J.L.; Yang, P.; Miao, L.X.; Ye, B. Analysis of the barriers towidespread adoption of electric vehicles in Shenzhen China. Sustainability 2017, 9, 522. [CrossRef]

30. He, X.; Zhan, W.; Hu, Y. Consumer purchase intention of electric vehicles in China: The roles of perception and personality. $J$. Clean. Prod. 2018, 204, 1060-1069. [CrossRef]

31. Thøgersen, J.; Ebsen, J.V. Perceptual and motivational reasons for the low adoption of electric cars in Denmark. Transp. Res. Part F Traffic Psychol. Behav. 2019, 65, 89-106. [CrossRef]

32. Carley, S.; Siddiki, S.; Nicholson-Crotty, S. Evolution of plug-in electric vehicle demand: Assessing consumer perceptions and intent to purchase over time. Transp. Res. Part D Transp. Environ. 2019, 70, 94-111. [CrossRef]

33. Long, Z.; Axsen, J.; Kormos, C.; Goldberg, S. Latent demand for zero-emissions vehicles in Canada (Part 1): Insights from a design space exercise. Transp. Res. Part D Transp. Environ. 2019, 67, 51-66. [CrossRef]

34. Higueras-Castillo, E.; Molinillo, S.; Coca-Stefaniak, J.A.; Liébana-Cabanillas, F. Perceived value and customer adoption of electric and hybrid vehicles. Sustainability 2019, 11, 4956. [CrossRef]

35. Higueras-Castillo, E.; Kalinic, Z.; Marinkovic, V.; Liébana-Cabanillas, F.J. A mixed analysis of perceptions of electric and hybrid vehicles. Energy Policy 2020, 136, 111076. [CrossRef]

36. Dua, R.; White, K. Understanding latent demand for hybrid and plug-in electric vehicles using large-scale longitudinal survey data of US new vehicle buyers. Energy Effic. 2020, 13, 1063-1074. [CrossRef]

37. Bunce, L.; Harris, M.; Burgess, M. Charge up then charge out? Drivers' perceptions and experiences of electric vehicles in the UK Transp. Res. Part A Policy Pract. 2014, 59, 278-287. [CrossRef]

38. Bailey, J.; Miele, A.; Axsen, J. Is awareness of public charging associated with consumer interest in plug-in electric vehicles? Transp. Res. Part D Transp. Environ. 2015, 36, 1-9. [CrossRef]

39. Axsen, J.; Langman, B.; Goldberg, S. Confusion of innovations: Mainstream consumer perceptions and misperceptions of electric-drive vehicles and charging programs in Canada. Energy Res. Soc. Sci. 2017, 27, 163-173. [CrossRef]

40. Sovacool, B.K.; Kester, J.; Heida, V. Cars and kids: Childhood perceptions of electric vehicles and sustainable transport in Denmark and the Netherlands. Technol. Forecast. Soc. Chang. 2019, 144, 182-192. [CrossRef]

41. Shetty, D.K.; Shetty, S.; Raj Rodrigues, L.; Naik, N.; Maddodi, C.B.; Malarout, N.; Sooriyaperakasam, N. Barriers to widespread adoption of plug-in electric vehicles in emerging Asian markets: An analysis of consumer behavioral attitudes and perceptions. Cogent Eng. 2020, 7, 1796198. [CrossRef]

42. Morton, C.; Anable, J.; Nelson, J.D. Consumer structure in the emerging market for electric vehicles: Identifying market segments using cluster analysis. Int. J. Sustain. Transp. 2017, 11, 443-459. [CrossRef]

43. Nosi, C.; Pratesi, C.A.; D'agostino, A. A benefit segmentation of the Italian market for full electric vehicles. J. Mark. Anal. 2014, 2, 120-134. [CrossRef]

44. Kubiczek, J.; Hadasik, B. Segmentation of Passenger Electric Cars Market in Poland. World Electr. Veh. J. 2021, 12, 23. [CrossRef]

45. Hauff, K.; Pfahl, S.; Degenkolb, R. Taxation of electric vehicles in Europe: A methodology for comparison. World Electr. Veh. J. 2018, 9, 30. [CrossRef]

46. Hidrue, M.K.; Parsons, G.R. Is there a near-term market for vehicle-to-grid electric vehicles? Appl. Energy 2015, 151, 67-76. [CrossRef]

47. Bobanac, V.; Pandzic, H.; Capuder, T. Survey on electric vehicles and battery swapping stations: Expectations of existing and future EV owners. In Proceedings of the 2018 IEEE International Energy Conference (ENERGYCON), Limassol, Cyprus, 3-7 June 2018; pp. 1-6. [CrossRef]

48. Jenn, A.; Laberteaux, K.; Clewlow, R. New mobility service users' perceptions on electric vehicle adoption. Int. J. Sustain. Transp. 2018, 12, 526-540. [CrossRef]

49. Brown, M.A.; Soni, A. Expert perceptions of enhancing grid resilience with electric vehicles in the United States. Energy Res. Soc. Sci. 2019, 57, 101241. [CrossRef]

50. Berliner, R.M.; Hardman, S.; Tal, G. Uncovering early adopter's perceptions and purchase intentions of automated vehicles: Insights from early adopters of electric vehicles in California. Transp. Res. Part F Traffic Psychol. Behav. 2019, 60, 712-722. [CrossRef] 
51. Ajanovic, A.; Haas, R. Dissemination of electric vehicles in urban areas: Major factors for success. Energy 2016, 115, 1451-1458. [CrossRef]

52. Wang, S.; Wang, J.; Li, J.; Wang, J.; Liang, L. Policy implications for promoting the adoption of electric vehicles: Do consumer's knowledge, perceived risk and financial incentive policy matter? Transp. Res. Part A Policy Pract. 2018, 117, 58-69. [CrossRef]

53. Kim, M.K.; Oh, J.; Park, J.H.; Joo, C. Perceived value and adoption intention for electric vehicles in Korea: Moderating effects of environmental traits and government supports. Energy 2018, 159, 799-809. [CrossRef]

54. Xu, Y.; Zhang, W.; Bao, H.; Zhang, S.; Xiang, Y. A SEM-neural network approach to predict customers' intention to purchase battery electric vehicles in China's Zhejiang Province. Sustainability 2019, 11, 3164. [CrossRef]

55. Etikan, I.; Musa, S.A.; Alkassim, R.S. Comparison of convenience sampling and purposive sampling. Am. J. Theor. Appl. Stat. 2016, 5, 1-4. [CrossRef]

56. Mahmud, M.S.; Huang, J.Z.; Salloum, S.; Emara, T.Z.; Sadatdiynov, K. A survey of data partitioning and sampling methods to support big data analysis. Big Data Min. Anal. 2020, 3, 85-101. [CrossRef]

57. Villacís, B.; Carrillo, D.; INEC. País Atrevido: La Nueva Cara Sociodemográfica del Ecuador; Technical Report; Instituto Nacional de Estadistica y Censos: Quito, Ecuador, 2012.

58. Olmedo, D. Ecuador: El Ingreso Promedio por Trabajador es Menor que el Salario Básico. Available online: https://www. lahora.com.ec/noticia/1102258596/ecuador-el-ingreso-promedio-por-trabajador-es-menor-que-el-salario-basico (accessed on 8 November 2021).

59. Dahiya, R.C.; Gurland, J. Pearson chi-squared test of fit with random intervals. Biometrika 1972, 59, 147-153. [CrossRef] 